русских корней, прежде всего, за счет лакунарности русской словообразовательной системы и заполнения «пустых клеток» потенциально возможными производными.

\title{
Литература:
}

1. Резанова 3. И. Функциональный аспект словообразования: Русское производное имя. Томск: Изд-во Томского ун-та, 1996. 218 с.

2. Петрухина Е. В. Возможности, функции и конкуренты словопроизводства в современном русском языке. Новые явления 6 славянском словообразовании: система и функиионирование: Доклады XI Международной научной конференции Комиссии по славянскому словообразованию при Международном комитете славистов / Под ред. проф. Е. В. Петрухиной. Москва: Филологический факультет МГУ им. М.В. Ломоносова, 2010. - Режим доступа: https://www.portalslovo.ru/philology/45939.php

3. Скляревская Г. Н. Слово в меняющемся мире: русский язык начала XXI столетия: состояние, проблемы, перспективы. Исследования по славянским языкам. № 6. Сеул, 2001. С. 177-202.

DOI https://doi.org/10.30525/978-9934-26-073-5-1-19

\section{СЕМАНТИЧНІ ОСОБЛИВОСТІ ПОВНИХ ГОМОГЕННИХ МІЖМОВНИХ ОМОНІМІВ-ІМЕННИКІВ В УКРАЇНСЬКІЙ І БІЛОРУСЬКІЙ МОВАХ}

\author{
Щербина Д. В. \\ аспірант кафедри української мови \\ Криворізького державного педагогічного університету \\ м. Кривий Ріг, Дніпропетровська область, Україна
}

Інтенсивні контакти між двома мовами сприяють, з одного боку, їх обопільному збагаченню, а 3 другого - породжують небажану інтерференцію, яка найчастіше виявляється у відхиленні від норм однієї 3 мов під впливом іншої. Серед головних причин такої інтерференції міжмовна омонімія. Міжмовні омоніми становлять великі труднощі у практиці лексикографічної та перекладацької роботи або під час навчання іноземних мов, тож науковий інтерес до цієї багатогранної проблеми дедалі зростає. 
Останніми роками 3'явилося чимало наукових і прикладних праць, присвячених слов'янській міжмовній омонімії: українсько-польській (І. Кононенко, О. Співак), українсько-російській (В. Манакін, О. Федорчук), білорусько-чеській (Н. Івашина, О. Руденко), білорусько-польській (Р. Калета), та ін. С праці на матеріалі трьох, чотирьох і більшої кількості слов'янських мов. Однак в україністиці ще немає комплексного аналізу українсько-білоруської міжмовної омонімії, що й визначило актуальність нашого дослідження.

Під міжмовними омонімами ми розуміємо різномовні слова, які збігаються формою усно, на письмі чи в межах регулярних відповідностей (фонетичних, графічних, орфографічних, акцентологічних, морфемно-словотвірних), наявних між порівнюваними мовними системами, $\mathrm{i}$ цілком або частково різняться змістом [9]. Міжмовні омоніми систематизують за різними ознаками, але найчастіше в основі їх класифікації лежать формальний, етимологічний, частиномовний або семантичний принципи. Спираючись на логічну схему формально-змістової відповідності, відношення між повними міжмовними омонімами можна схарактеризувати як семантичне виключення, а між частковими міжмовними омонімами - як семантичне включення або семантичний перетин [2, с. $122-149 ; 3 ; 7$, с. 111-123; 8, с. 55-62].

Джерельну базу нашого дослідження становлять українськобілоруські омонімічні опозиції, виявлені порівнянням семантичних структур лексем, узятих зі словника української мови в 11 томах [4], словника української мови у 20 томах [5] i тлумачного словника білоруської мови у 5 томах (6 книгах) [6]. Для аналізу також використано відомості з етимологічного словника української мови в 7 томах [1] та етимологічного словника білоруської мови [10].

Повні міжмовні омоніми, тобто омоніми з відношенням семантичного виключення, можуть виникати внаслідок неоднакового семантичного розвитку етимологічно тотожних лексем, через випадковий збіг форми слів різного походження або під впливом внутрішньомовної омонімії. Зазвичай у міжмовних омонімів, що з'явилися в результаті неоднакового семантичного розвитку від етимологічно тотожних слів, навіть за відсутності спільної частини в значеннях, зберігаються часом сліди колишнього семантичного зв'язку.

Основну частину міжмовних омонімів цієї групи становлять іменники. Найменше серед них тих, що в обох мовах означають істоту. Вони, як правило, досить відмінні значенням. Порівняймо укр. лайда́к [ч., діал.] '1) убога бездомна людина; 2) як лайливе слово’ і біл. лайда́к [ч., розм., зневажл.] 'лінива, варта зневаги людина; ледар, 
нероба, гультяй', укр. зна́йда [ч. і ж., розм., заст.] 'знайдена дитинапідкидьок' і біл. зна́йда [ж.] '1) собака, навчений відшукувати по слідах; 2) [перен., розм.] слідець, шпигун'.

Набагато більше зафіксовано випадків, коли іменник однієї мови окреслює істоту, а іменник другої мови - неістоту. Значення іменниканеістоти при цьому може бути найрізноманітнішим (назва речі, пристрою, явища природи, частини чого-небудь тощо): укр. драч [ч.] '1) [розм.] місце, де чинять здирство // здирство; 2) [діал.] просорушка' i біл. драч [ч.] 'невеликий птах родини пастушкових; деркач', укр. нава́льниця [ж.] 'шахтарка, яка навантажує вагонетки' і біл. навальніца [ж.] '1) негода $з$ блискавкою, громом, дощем або градом та сильним вітром; гроза; 2) [перен.] бурхливі, грізні події // небезпека'.

Часом іменник-неістота в таких парах унаслідок розвитку переносних значень на основі характерних рис набуває i значення істоти: укр. гарга́pa [ж., діал.] 'сварлива жінка' і біл. гарzа́ра [ж., розм.] '1) громіздка річ; одоробло; 2) товстуха, гладуха’ а іменник-істота - значення неістоти: укр. гладу́ [ч.] '1) [розм.] товстун; 2) [діал.] глек, глечик' і біл. гладу́н [ч.] 'трав'яниста рослина родини гвоздикових; остудник'.

Іменникові повні міжмовні омоніми можуть бути складниками формально співвідносних і семантично тотожних фразем (укр. бúmu ба́йди = біл. біць ба́йды = 'ледарювати', хоч на синхронному зрізі укр. ба́йда $\neq$ біл. ба́йда: укр. ба́йда [рідко] '1) [ч. і ж.] гульвіса; 2) [тільки ж., діал.] шматок чогось ламкого або крихкого', біл. бáŭda [ж., розм.] '1) рибальський човен; 2) [заст.] стовп, забитий у грунт; паля’) або належати до однакових тематичних шарів. Серед останніх ми, зокрема, зафіксували:

- назви виробів із тканини та їхніх деталей: укр. шири́нка [ж., заст.] 'шматок тканини, рушник, скатерть, хустка' і біл. шырь́нка [ж.] 'розріз у штанях; ширінька';

- назви об’єктів тваринного та рослинного світу: укр. ко́рша́к [ч.] 'шуліка' і біл. ко́ршак (карша́к) [ч., розм.] 'яструб', укр. сморж [ч.] 'отруйний гриб із звивисто-складчастою шапинкою; лат. Gyromitra Fr.' i біл. сморж⿻ [ч.] 'їстівний гриб із звивисто-складчастою шапинкою; зморшка; лат. Morchella Dill.';

- назви речей хатнього й господарського вжитку або їхніх частин: укр. кульба́ка [ж., заст.] 'сідло’ і біл. кульба́ка [ж. розм.] 'костур, ковінька';

- назви будівель та їхніх складників: укр. стодо́ла [ж.] 'клуня' і біл. стадо́ла [ж., заст.] '1) стайня в заїзді; 2) хлів, стайня взагалі; 3) [розм.] незатишне, невпорядковане помешкання; хлів; 
- економічна лексика: укр. кошт [ч., перев. мн.] '1) гроші, капітал, матеріальні цінності; 2) [рідко] витрати, видатки; 3) [заст.] забезпечення, постачання' і біл. кошт [ч.] 'виражена в грошах цінність; вартість;

- назви органів, систем органів людини і тварини: укр. ще́лепа [ж.] '1) одна 3 двох протилежних міцних структур, розміщених коло ротової порожнини // частина обличчя або морди, де міститься ця структура; 2) пластинка зі штучними зубами; зубний протез; 3) [перен.] деталь механізму, призначена для хапання та подрібнення чого-небудь' i біл. шчэ́лепь [мн.] 'зябра'.

Деякі етимологічно споріднені й цілком відмінні значенням іменники, охоплені міжмовною омонімією, зберігають семантичну подібність на підставі однакових фізичних властивостей та характеристик: укр. кра́ска [ж., розм.] '1) фарба; 2) рум’янець' і біл. кра́ска [ж., розм.] 'квітка' (забарвлення); укр. надві́p'я [с.] 'подвір'я' і біл. надво́р'е [с.] 'погода' (просторовість); укр. ла́нтух [ч.] '1) великий мішок; 2) міра, що дорівнює вмістові такого мішка; 3) [перен.] велика кількість; 4) [перен.] неповоротка, неспритна людина; 5) як лайливе слово’ і біл. ланту́x [ч., розм.] 'живіт, пузо, черево' (форма)'.

Серед повних міжмовних омонімів $є$ чимало абстрактних $\mathrm{i}$ конкретних іменників дієслівного походження, які, розійшовшись значеннями (місце, засіб, стан, наслідок дії або назва самої дії), зберігають щонайтісніший зв'язок із твірними дієсловами (іноді навіть тотожними в обох мовах): укр. вимо́ва [ж.] 'спосіб вимовляння // особливості звукової системи мови' і біл. выммо́в [ж.] 'догана', укр. пода́ння́ [c.] '1) дія за знач. пода́mu; 2) письмова заява' і біл. пада́нне [с.] 'переказ, легенда', укр. поставни́к [ч.] '1) [церк.] великий церковний свічник; ставник; 2) [заст.] велика свічка' і біл. пастайні́к [ч.] 'загорода, загін, обора'.

Отже, розглянувши семантичні особливості українсько-білоруських повних гомогенних міжмовних омонімів-іменників, ми з'ясували, що вони можуть бути компонентами формально співвідносних і семантично тотожних фразем або належати до однакових тематичних шарів. Деякі етимологічно споріднені й цілком відмінні значенням іменники, охоплені міжмовною омонімією, зберігають семантичну подібність на підставі однакової сприйманості органами чуття або наявності схожих характеристик.

\section{Література:}

1. Етимологічний словник української мови: у 7 т. / ред. кол.: О. Мельничук (гол.) та ін.; АН УРСР, НАН України, Ін-т мовознавства ім. О. Потебні. Київ: Наук. думка, 1982-2012. Т. 1-6. 
2. Манакин В. Сопоставительная лексикология. Киев, 2004. 327 с.

3. Міхалевіч А., Мордас Н. Міжмоўная аманімія як праблема сучаснай лексікаграфіi. Усходнеславянскія мовы $\check{y}$ сучаснай лексікаграфіi : зб. навук. арт. Мінск, 2015. С. 79-81.

4. Словник української мови: в 11 т. / гол. ред. І. Білодід; АН УРСР, Ін-т мовознавства ім. О. Потебні. Київ: Наук. думка, 1970-1980. URL: http://sum.in.ua.

5. Словник української мови: у 20 т. / гол. наук. ред. В. Русанівський; НАН України, Укр. мов.-інформ. фонд. Київ: Наук. думка, 2010-2018. T. 1-9. URL: https://sum20ua.com.

6. Тлумачальны слоўнік беларускай мовы: у 5 т. (6 кн.) / гал. рэд. К. Атраховіч (К. Крапіва); АН БССР, Ін-т мовазнаўства імя Я. Коласа. Мінск: БелСЭ, 1977-1984. URL: https://www.skarnik.by.

7. Федорчук Е. Межъязыковая омонимия и паронимия в близкородственных языках (на материале русского и украинского языков): дис. ... канд. филол. наук. Москва, 2001. 256 с.

8. Хуцишвили С. Славянские межъязыковые омонимы: дис. ... канд. филол. наук. Тбилиси: Тбилисский гос. ун-т им. И. Джавахишвили, 2010. 169 c.

9. Щербина Д. Повні українсько-білоруські міжмовні омоніми. Філологіка / Philologica: зб. наук. праць. Кривий Ріг, 2020. Вип. 21. C. $97-112$.

10. Этымалагічны слоўнік беларускай мовы / рэд. В. Мартынаў, Г. Цыхун; АН БССР, НАН Беларусі, Ін-т мовазнаўства ім. Я. Коласа. Мінск: Навука і тэхніка, Беларуская навука, 1978-2017. Т. 1-14.

DOI https://doi.org/10.30525/978-9934-26-073-5-1-20

\title{
УКРАЇНСЬКА НАУКОВА МОВА: НА ШЛЯХУ ДО «СУСПІЛЬСТВА ЗНАНЬ»
}

\author{
Ярова А. Г. \\ кандидат філологічних наук, \\ дочент кафедри мовної підготовки іноземних громадян \\ Сумського державного університету \\ м. Суми, Украӥна
}

«Суспільство знань» ante portas - констатують сучасні дослідники й обмірковують численні виклики нової економічної, соціокультурної 